\title{
Influence of Groundwater Discharge on Temporal Evolution in Two Wetlands of an Intensely Anthropized Area: Analysis Using an Integrated Approach
}

\author{
Francisco Sánchez-Martos ${ }^{1, *}$, José Manuel López-Martos ${ }^{2}$, Luis Molina Sánchez ${ }^{1}$, Juan Gisbert-Gallego ${ }^{1} \mathbb{D}$ \\ and Francisco Navarro-Martínez ${ }^{1}$ (D) \\ 1 Water Resources and Environmental Geology Research Group, Department of Biology \& Geology, \\ University of Almería, 04120 Almería, Spain; lmolina@ual.es (L.M.S.); jgisbert@ual.es (J.G.-G.); \\ fnm206@ual.es (F.N.-M.) \\ 2 Center for Scientific Collections, University of Almería, 04120 Almería, Spain; \\ josem.lopez.martos@juntadeandalucia.es \\ * Correspondence: fmartos@ual.es
}

\section{check for}

updates

Citation: Sánchez-Martos, F.; López-Martos, J.M.; Molina Sánchez, L.; Gisbert-Gallego, J.;

Navarro-Martínez, F. Influence of Groundwater Discharge on Temporal Evolution in Two Wetlands of an Intensely Anthropized Area: Analysis Using an Integrated Approach. Water 2021, 13, 697. https://doi.org/ 10.3390/w13050697

Academic Editor: Carlos Duque

Received: 29 December 2020

Accepted: 26 February 2021

Published: 5 March 2021

Publisher's Note: MDPI stays neutral with regard to jurisdictional claims in published maps and institutional affiliations.

Copyright: (c) 2021 by the authors. Licensee MDPI, Basel, Switzerland. This article is an open access article distributed under the terms and conditions of the Creative Commons Attribution (CC BY) license (https:/ / creativecommons.org/licenses/by/ $4.0 /)$.

\begin{abstract}
The Campo de Dalías is a coastal plain, which has undergone a significant change in land use and intensive exploitation of groundwater. A series of diverse data has been analyzed: aerial and satellite images (1956-2013), evolution of the water table (1973-2019), and exploitation of different aquifers (1964-2017). The results indicate: (1) increase in the surface area occupied by greenhouses, (2) increase in abstraction of groundwater, and (3) an opposite trend in the piezometric evolution of the two aquifers (deep and shallow). All this has had a significant effect on the evolution of the "Punta Entinas" wetland, which has shown a continuous increase in flooded surface area, especially pronounced since 1994. Its waters have intermediate hydrochemical characteristics between seawater and groundwater and reflect the local influence of groundwater on the wetland. The applied methodology is useful in areas with sustained human activity, land use changes, and intensive groundwater exploitation, and can contribute to the understanding of surface water-groundwater dependence and wetland management.
\end{abstract}

Keywords: human impacts; groundwater-surface interaction; groundwater-dependent ecosystems

\section{Introduction}

Wetlands show pronounced environmental gradients exhibiting a wide diversity of soils and biological communities in a small area [1]. This makes them ideal places to analyze the consequences of human activities on the evolution of ecosystems, since effects of human activities take place over relatively short periods of time and small zones and can be easily identified [2]. Land use changes represent one of the most extensive humaninduced impacts that can alter the hydrology of wetlands and lead to their degradation and eventual loss. This is likely to be especially intense in areas where intense land use changes are coupled with global climate change effects [3].

Knowledge of wetland dynamics has grown remarkably due to improvements in remote sensing [1]. From Landsat images, water bodies have been mapped, identifying land use changes that cause rapid and widespread loss of wetlands with negative consequences for biodiversity and ecosystem services [4-6]. These maps provide a snapshot of water extent [7], and even allow for water balance estimates [8]. All this makes it possible to identify that the extent of a flooded area plays a critical role in numerous processes: the energy balance between land and atmosphere [9], carbon and nitrogen cycles [10], and surface and groundwater exchange [11,12]. Even some changes in vegetation have been associated with increased periods of flooding observed in wetland [10].

Despite the recognition and protection of wetlands during the 20th century, their extent has decreased significantly, both inland wetlands (69-75\%) and coastal wetlands, 
which have seen a $62-63 \%$ reduction [13]. For the 214 sites studied in 22 countries of the Mediterranean, the area of natural wetland habitats decreased by 10\% from 1975 to 2005 [13]. The extent of the surface water is one of the abiotic factors that controls the functioning of the wetlands. Thus, small changes in the hydrological regime can cause substantial changes in ecosystem characteristics [14], and fluctuations in the flooded area and soil saturation control many of the ecosystem services they provide. Accordingly, controlling flood dynamics is vital for understanding the status and quality of associated ecosystems [15,16]. Changes in land use represent one of the most drastic human impacts, as they alter the hydrology of wetlands and reduce the surface area occupied by water, which leads to their loss and degradation $[17,18]$. There are numerous studies that investigate the inundation regime of wetlands and its relationship with rates of sea level rise, changes in local rainfall, surface runoff $[18,19]$ (among others), or flooding periods [2]. However, there are few studies that analyze the increase in flooded area of coastal and inland wetlands directly associated with agricultural activities and groundwater exploitation.

In the areas with an agricultural intense activity dependent on groundwater, managing the water involves diversification of water resources, fostering the use of desalinated water, and the reuse of wastewater [20,21]. The Sierra de Gador-Campo de Dalías system shows the complexity of managing water resources in semi-arid environments, where groundwater extraction must be suitable for groundwater management in agricultural areas [22], taking into account the importance of water management at basin scale [23]. These two points are especially important in areas such as the Campo de Dalías (CD), with major land use changes and considerable groundwater exploitation that has radically transformed the landscape [21].

This work focuses on two wetlands located in Campo de Dalías (CD) southeast Spain, where there have been significant changes in land use. All this has allowed the effect of human-related activities on the wetlands over for a long period to be analyzed. It considers jointly temporal data (point and spatial) related to groundwater and the agricultural activities. The main objective is to analyze and discuss the evolution of a series of processes/activities of human-related origin that affect the influence of groundwater on surface water dynamics, in two wetlands (inland and coastal) both dependent on groundwater.

\section{Materials and Methods}

\subsection{The Area}

The CD is a coastal plain of about $330 \mathrm{~km}^{2}$ in extent with a relatively gentle relief. To the north, it is bound by Sierra de Gádor, while its other edges are littoral and touch the Mediterranean Sea (Figure 1a). The area receives most of its surface water drainage from short, steep "ramblas", which flow from the southern face of the Sierra de Gádor and have no outflow to the sea.

The main aquifer materials in $\mathrm{CD}$ are dolomites and dolomitic limestones from the Triassic age, with a thickness that can surpass $1000 \mathrm{~m}$ and outcroppings that form the Sierra de Gádor. These materials progressively deepen below Neogene and Quaternary deposits in the CD. The impermeable Neogene materials confine the deep carbonate aquifer and separate it from a detritic shallow aquifer (Figure 1). The waters of deep carbonate aquifer are Mg-Ca-HCO3 type with low salinity and conductivity of less than $1000 \mu \mathrm{S} \cdot \mathrm{cm}^{-1}$. In the shallow aquifer they are $\mathrm{Mg}-\mathrm{Na}-\mathrm{Cl}$ type with conductivity in a range of $1500-4500 \mu \mathrm{S} \cdot \mathrm{cm}^{-1}$ [24]. This system represents the main source of water supply for the most productive fruit and vegetable sector in Europe. Managing water resources involves diversification of water resources, fostering the use of desalinated water as well as the reuse of wastewater $[20,21]$. The Sierra de Gádor-Campo de Dalías system shows the complexity of managing water resources in semi-arid environments, where groundwater extraction must be suitable for groundwater management in agricultural areas [22], taking into account the importance of water management at basin scale [23]. These two points are especially important in areas such as the $\mathrm{CD}$ with major land use changes and considerable 
groundwater exploitation that has radically transformed the landscape [21]. Groundwater exploitation has increased rapidly from the 1960s to the present. Initially, extractions were concentrated in the shallower aquifer mainly due to its easy access. In the 1990s, extractions from the shallow aquifer decreased, due to the salinization of its waters as a result of irrigation return flows and soil salinization [24]. This led to the search for other water resources and the deep carbonated aquifer began to be heavily exploited through deep drilling, reaching extraction volumes of $120 \times 106 \mathrm{~m}^{3} /$ year [20] as a result of its good water quality. The development of this process brought about the formation and evolution of the Balsa del Sapo inland wetland [25]. The Punta Entinas wetland is located on the coastal edge of $C D$, separated from the sea by a sand bar and dunes. The outcropping geological materials in its interior setting correspond to a powerful series of loams covered by sandy loams, sands, and calcarenites of the Pliocene age above which there are four levels of Tyrrhenian marine deposits [26].

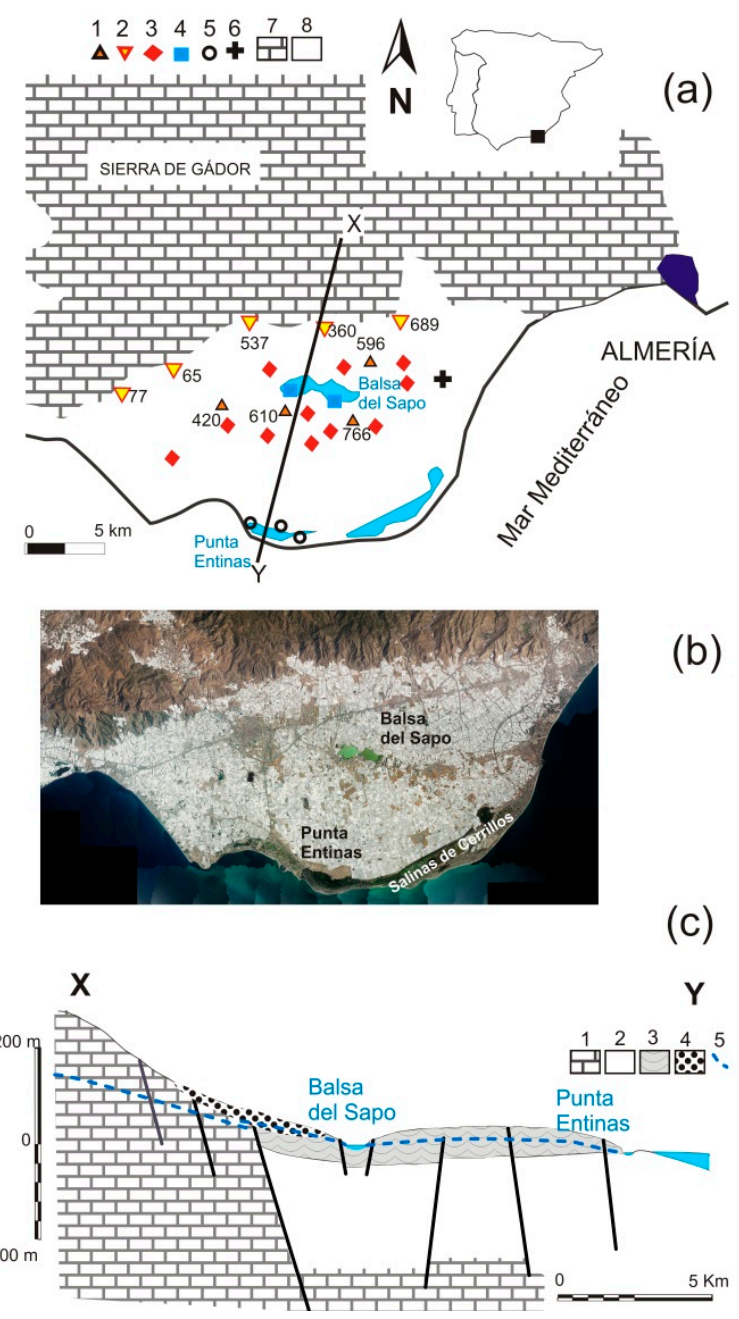

Figure 1. (a) Simplified geological map of Campo de Dalías showing the two wetlands and the location of the monitoring points. Water table (1: shallow aquifer, 2: deep aquifer), chemistry (3: shallow aquifer, 4: Balsa del Sapo, 5: Punta Entinas), 6: La Mojonera rainfall station, 7: carbonate deposits (limestone and dolostone), 8: neogene detritic materials. The $\mathrm{X}-\mathrm{Y}$ line identified the location of the cross-section presented in C. The location of the study area is marked with a square on the map. (b) Image of the Campo de Dalías. All the area in white is covered by greenhouses. Date 2016. Source: Plan Nacional de Ortografía. Government of Spain. (c) Schematic geological crosssection. 1: Carbonate deposits (limestone and dolostone); 2: impermeable materials (marl and silt); 3: calcarenite; 4: gravel. 5: water table. Based on [20,27]. 
The intensive agricultural activity during the 1970s, together with poor natural soil development, led to a system that involved quarrying silt and clay deposits that could be used as soil in the greenhouses [20]. The abandonment of these quarries brought about the formation of Balsa del Sapo wetland in the central part of the CD. Along the coastal strip, there are two coastal wetlands (Punta Entinas and Salinas de Cerrillos). The wetlands consist of two partially-silted tidal lagoons, separated from the sea by sandbanks and dunes, which developed extensively throughout the Holocene [20]. Salinas de Cerrillos have undergone human-related changes whereas Punta Entinas has not been affected by human-related changes.

\subsection{Data}

In order to analyze the factors that affect the evolution of the wetlands, different elements were considered from a hydrological point of view. The rainfall data comes from the meteorological station La Mojonera (FIAPA, Andalusia Regional Government) near the wetlands (Figure 1). The station, $5 \mathrm{~km}$ from Balsa del Sapo, has daily rainfall data available from 1967 to 2013. The water level has has been sampled in nine boreholes, specifically located in the two aquifers. They were monitored over recent decades (from 1960 to 2015) with annual sampling frequency. Physico-chemical data from 11 samples of the shallow aquifer have been considered (Table 1).

Table 1. Physico-chemical data of surface and groundwater. E.C.: electrical conductivity $\left(\mu \mathrm{S} \cdot \mathrm{cm}^{-1}\right)$, chemical concentrations in $(\mathrm{mg} / \mathrm{l})$.

\begin{tabular}{|c|c|c|c|c|c|c|c|c|c|c|c|}
\hline \multicolumn{2}{|c|}{ Water } & Date & E.C. & $\mathrm{Cl}$ & $\mathrm{SO} 4$ & $\mathrm{HCO}_{3}$ & $\mathrm{NO}_{3}$ & $\mathrm{Na}$ & $\mathrm{Mg}$ & $\mathrm{Ca}$ & $\mathbf{K}$ \\
\hline \multicolumn{2}{|c|}{ Sea water } & 26-06-09 & & 20,809 & 2950 & 148 & $<0.45$ & 11,720 & 1428 & 460 & 82.1 \\
\hline \multirow{9}{*}{ 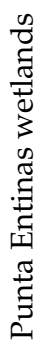 } & ENT 04 & 01-09-05 & 73,200 & 33,711 & 4232 & 260 & 49 & 23,100 & 900 & 772 & 560.0 \\
\hline & ENT 01 & 01-09-05 & 21,800 & 7927 & 905 & 291 & 44 & 5480 & 216 & 212 & 240.0 \\
\hline & ENT 04 & 01-05-09 & 64,300 & 26,587 & 4952 & 159 & 0 & 14,039 & 1637 & 1489 & 564.3 \\
\hline & ENT 01 & 01-05-09 & 62,500 & 25,631 & 5088 & 190 & 0 & 13,936 & 1537 & 1493 & 541.2 \\
\hline & ENT 02 & $04-02-13$ & 44,500 & 19,444 & 4307 & 238 & 17 & 9312 & 1585 & 1103 & 435.0 \\
\hline & ENT 01 & $04-02-13$ & 34,520 & 13,091 & 2965 & 232 & 33 & 6316 & 1110 & 774 & 291.0 \\
\hline & ENT 01b & $04-02-13$ & 3485 & 1004 & 664 & 348 & 30 & 682 & 168 & 177 & 31.5 \\
\hline & ENT 02 & $28-05-13$ & 45,410 & 20,843 & 4818 & 201 & $<0.45$ & 10,247 & 1261 & 1064 & 482.8 \\
\hline & ENT 01 & $28-05-13$ & 3374 & 1191 & 570 & 500 & $<0.45$ & 682 & 168 & 170 & 35.0 \\
\hline \multirow{11}{*}{ 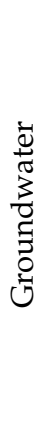 } & 630-D & $26-06-07$ & 4440 & 974 & 606 & 360 & 296 & 611 & 179 & 188 & 0.5 \\
\hline & 140-D & $26-06-07$ & 3150 & 703 & 302 & 305 & 41 & 402 & 117 & 105 & 0.3 \\
\hline & $162-\mathrm{D}$ & $26-06-07$ & 1887 & 322 & 183 & 403 & 125 & 166 & 103 & 86 & 0.5 \\
\hline & 162-D0 & $26-06-07$ & 1845 & 355 & 242 & 354 & 170 & 243 & 111 & 103 & 0.5 \\
\hline & $168-\mathrm{D}$ & $26-06-07$ & 2480 & 464 & 222 & 336 & 177 & 257 & 112 & 106 & 0.2 \\
\hline & 184-D & $26-06-07$ & 3080 & 280 & 138 & 311 & 73 & 148 & 53 & 116 & 0.2 \\
\hline & 207-D & $26-06-07$ & 2180 & 620 & 138 & 246 & 53 & 308 & 108 & 104 & 0.4 \\
\hline & 236-D & $26-06-07$ & 2600 & 539 & 228 & 299 & 93 & 282 & 116 & 84 & 0.5 \\
\hline & 239-D & $26-06-07$ & 1462 & 230 & 123 & 299 & 110 & 99 & 100 & 71 & 0.2 \\
\hline & 573-D & $26-06-07$ & 3890 & 865 & 363 & 329 & 98 & 448 & 137 & 136 & 0.5 \\
\hline & $623-\mathrm{D}$ & $26-06-07$ & 3530 & 405 & 135 & 384 & 55 & 219 & 62 & 85 & 0.2 \\
\hline
\end{tabular}

In order to understand the characteristics of the water, a series of physico-chemical parameters were determined for the groundwater of the shallowest aquifer and the Punta Entinas wetlands. The electrical conductivity (EC) was determined in situ using an $\mathrm{HACH}$ HQ40D conductivity meter (Loveland, CO, USA). Samples were taken in two bottles: one for anion analysis (only filtered) and one for cation analysis (filtered and acidified to $\mathrm{pH}$ 2). In addition, they were filtered using a $0.45 \mu \mathrm{m}$ Millipore filter and stored in polyethylene bottles at $4{ }^{\circ} \mathrm{C}$. The alkalinity of the water $\left(\mathrm{HCO}_{3}{ }^{-}\right)$is determined in the field by titration. Samples for cation analysis were acidified to $\mathrm{pH} 2$ with ultrapure grade nitric acid $(70 \%)$ to prevent absorption or precipitation. For anion sample composition, $\mathrm{Cl}^{-}$, $\mathrm{SO}_{4}{ }^{2-}, \mathrm{Ca}^{2+}, \mathrm{Mg}^{2+}, \mathrm{Na}^{+}$, and $\mathrm{K}^{+}$was determined by ICP-MS (inductively coupled plasma 
mass spectrometry) at the ACME Laboratories (Vancouver, BC, Canada). The data from Balsa del Sapo extend over a period of nine years and are based on previously published data [25].

The data available for each wetland is different because of its different genesis and evolution. In the Balsa del Sapo wetland, the surface water elevation is measured on a daily basis, through a water-level monitoring, sensors that measure the total pressure at a $24-h$ time interval. Atmospheric pressure transducers were installed nearby to compensate for the measurements of the above-mentioned sensors. In order to understand the evolution of the coastal wetland (Punta Entinas), an analysis of aerial images carried out for the period between 1957 and 2013 (Table 2), using images that approximate ten-year sequences. The images before 1994 correspond to photographs taken by conventional flights obtained with physical support and later digitized. Images after 1994 correspond to orthoimages (see details in Table 2).

Table 2. Aerial photographs and orthophotographs used.

\begin{tabular}{cccccc}
\hline Year & Month & Source (2) & Type (1) & Scale & Observations \\
\hline 1956 & January & REDIAM & O & $1: 45,0000$ & American flight: series B \\
1974 & September & IECA & F & $1: 25,000$ & \\
1985 & Summer & REDIAM & O & & $(4)$ \\
1994 & December & IECA & F & $1: 20,000$ & \\
2005 & Spring & REDIAM & O & $1: 20,000$ & ODA (3) \\
2013 & Spring & REDIAM & O & & ODA \\
\hline
\end{tabular}

(1) $\mathrm{O}$ = orthophotography; $\mathrm{F}$ = still frame. (2) REDIAM: Andalusia Regional Government Environmental Information Network. IECA: Andalusia Institute of Cartography and Statistics. (3) ODA: Andalusia Digital Orthophotography. (4) We have assigned the year 1985 to these photographs and we have found slight temporal differences to those we have dated (1984 from IECA). The interpretation of the image allows us to place it in the summer.

The image processing was performed over the hydrological basin slope down to the wetland of Punta Entinas using the digital model of the land obtained from Andalusia Digital Orthophotography, from the year 2001-2002 with a resolution of $10 \mathrm{~m}$. The interpretation was done manually, analyzing the images from 1956 and 1974 with a stereoscope. The interpretation of the aerial images is done in a non-automatic way, manually using GIS (Arc GIS) (ESRI, Redlands, CA, USA). A difference is drawn between traditional crops (essentially rainfed cereals and some tomato crops) and greenhouse crops for the agricultural plots. For the analysis of the images in the surroundings closest to the wetland, the following areas were identified: surface water (flooded areas at the time of photography, including those with clear evidence of flooding), salt marsh (high density Quenopodiaceae formations), floodable salt marsh (seasonally flooded), salt marsh with Sabinar-Lentiscar (ecotone areas between the dunes with arborescent vegetation of Juniperus phoenicea subsp. turbinata and Pistacia lentiscus and salt marsh, that form a dense patch with plants of bush structure indicating that they are not found in seasonally flooded areas), reed-beds (based on changes between the height, density and texture of the vegetation) and small islands (small isolated areas on which salt marsh vegetation is found, sometimes dotted around in the form of reeds and halophytes). Their presence links to the growth of the surface water and the flooding of new spaces.

\section{Results}

The Punta Entinas wetland represents the natural conditions of a coastal wetland. The total area of the wetland, including the different environments that it is formed by, increased from 1956 to 2013 (Table 3 and Figure 2a). This evolution features three different trend intervals. The growth was intense between 1956 and 1974, slowing down between 1974 and 1994, and then from 1994 it increased once again. Considering only the extent of the flooded area, the evolution was slightly different (Figure 2a). It remained constant until 1994 and from then, the increase was more pronounced, especially in the period 1994-2004. By 2013, the flooded areas represented $75 \%$ of the total area of the wetland. A more detailed 
analysis shows that the different mapped environments showed a similar scenario until 1994, with a noticeable dominance of the salt marsh. However, in the period 1956-1974, there was a certain balance between the size of the salt marsh and the floodable salt marsh From 1994 onwards, the floodable salt marsh disappeared and was completely occupied by water, which is now the dominant environment.

Table 3. Areas (hectares) defined by image processing, separating different environments. Modified from [28]. 1: Surface water; 2: floodable salt marsh; 3: reed-beds; 4: small islands; 5: salt marsh; 6: salt marsh with Sabinar-lentiscar.

\begin{tabular}{|c|c|c|c|c|c|c|c|}
\hline & Zones & 1956 & 1974 & 1984 & 1994 & 2004 & 2013 \\
\hline \multirow{2}{*}{ Crops } & Greenhouse & 0 & 0.78 & 610.57 & 1125.14 & 1559.23 & 1610.52 \\
\hline & Traditional & 476.05 & 4.18 & 0 & 0 & 0 & 0 \\
\hline \multirow{7}{*}{ 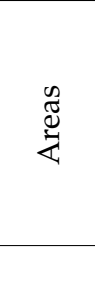 } & 6 & 4.55 & 5.22 & 6.44 & 5.90 & 5.83 & 13.76 \\
\hline & 5 & 42.69 & 68.25 & 75.11 & 65.25 & 27.21 & 19.90 \\
\hline & 4 & 1.37 & 3.34 & 2.55 & 1.83 & 2.92 & 0.60 \\
\hline & 3 & 18.97 & 18.87 & 28.65 & 28.88 & 32.02 & 22.91 \\
\hline & 2 & 47.27 & 52.82 & 39.34 & 49.63 & 0 & 0 \\
\hline & 1 & 29.86 & 29.07 & 28.33 & 31.98 & 130.40 & 154.14 \\
\hline & Total & 144.70 & 177.57 & 180.41 & 183.46 & 198.39 & 211.32 \\
\hline
\end{tabular}
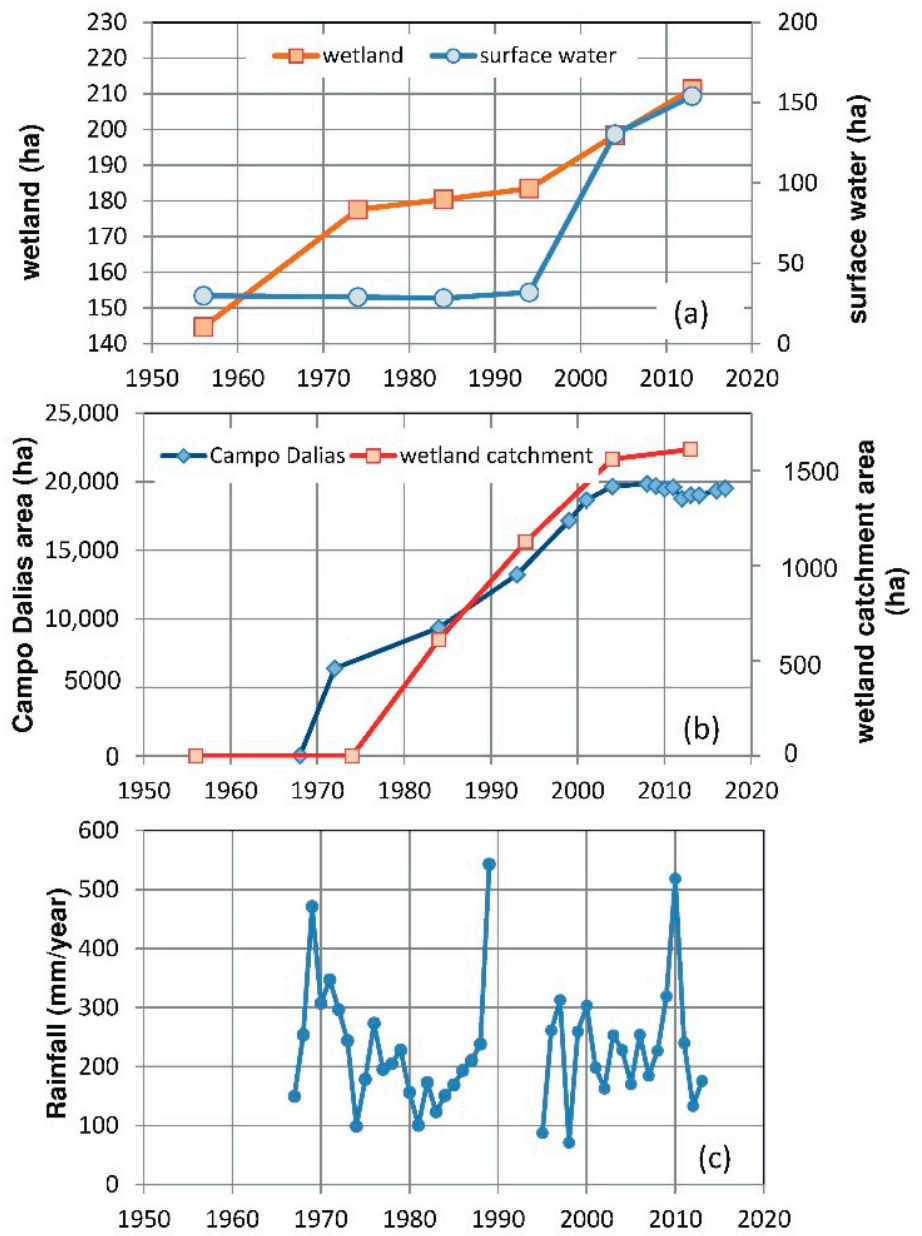

Figure 2. (a) Evolution of the total area (hectares) occupied by the wetland including all mapped environments and the area occupied by surface water. (b) Evolution of the land area occupied by greenhouses throughout the Campo de Dalías (CD) and in the coastal wetland catchment area. (c) Annual rainfall, La Mojonera station. 
In the Punta Entinas wetland, samples were taken from three points over six years (Table 1). The water exhibits a sodium chloride facies and its salinity is highly varied $\left(3337 \mu \mathrm{S} \cdot \mathrm{cm}^{-1}-73,200 \mu \mathrm{S} \cdot \mathrm{cm}^{-1}\right)$. Point ENT 04, located closer to the sea, has higher salinity $\left(73,200 \mu \mathrm{S} \cdot \mathrm{cm}^{-1}-64,300 \mu \mathrm{S} \cdot \mathrm{cm}^{-1}\right)$ and a slightly higher ionic content than seawater, as a result of evaporation processes. The points ENT 01 and ENT 02 are located in the innermost part of the wetland and their salinity is lower than seawater, ranging between $\left.44,500 \mu \mathrm{S} \cdot \mathrm{cm}^{-1}-3385 \mu \mathrm{S} \cdot \mathrm{cm}^{-1}\right)$. These lower values reflect the existence of other processes in addition to both marine influence and evaporation processes, two significant factors in coastal areas.

In order to analyze the evolution of the surface area occupied by wetland, the elements that have an effect on the system, from a hydrological point of view, are considered. The evolution of rainfall was very irregular and did not show any particular trend (Figure 2c). The precipitation regime does not show any direct relation with the increase in flooded surface area, a trend that has to be then be related to other factors. The most significant modification in the wetland environment relates to land use changes that may directly affect groundwater use. In the $\mathrm{CD}$, there has been a reduction in traditional crops and an increase in the area occupied by greenhouses (Figure $2 \mathrm{~b}$ and Table 3 ), which experienced intense and continuous growth between 1960 (30 ha) and 2004 (19,665 ha). From the image processing, this change has been accurately detected in the drainage basin towards the coastal wetland (Figure 3 and Table 3). Data from 1956 show that agricultural activities were limited exclusively to traditional crops, with a marked reduction in 1974 and total disappearance in 1984. This trend is associated with a continued increase in the greenhouse surface area, very similar to that experienced throughout the CD (Figure 2b). This is a change that has affected drastically and complexly both surface and groundwater interactions in the wetland environment. On the one hand, the modification of the type of agricultural activities has meant an increase in the impermeable surface, which has contributed to an increase in surface runoff towards Punta Entinas wetland. On the other hand, the increase in the area under cultivation and irrigation has led to a rise in the irrigation returns that infiltrate directly into the shallow aquifer, resulting in the gradual rise of its water table [28], which can increase the groundwater discharge into the wetland. These two processes can increase surface (episodes of extreme rainfall) and groundwater inputs into the wetland, whose flooded surface area has shown an upward trend, especially in the period 1984-1994, then with more intense relative increase in 1994 (Figure 3). 

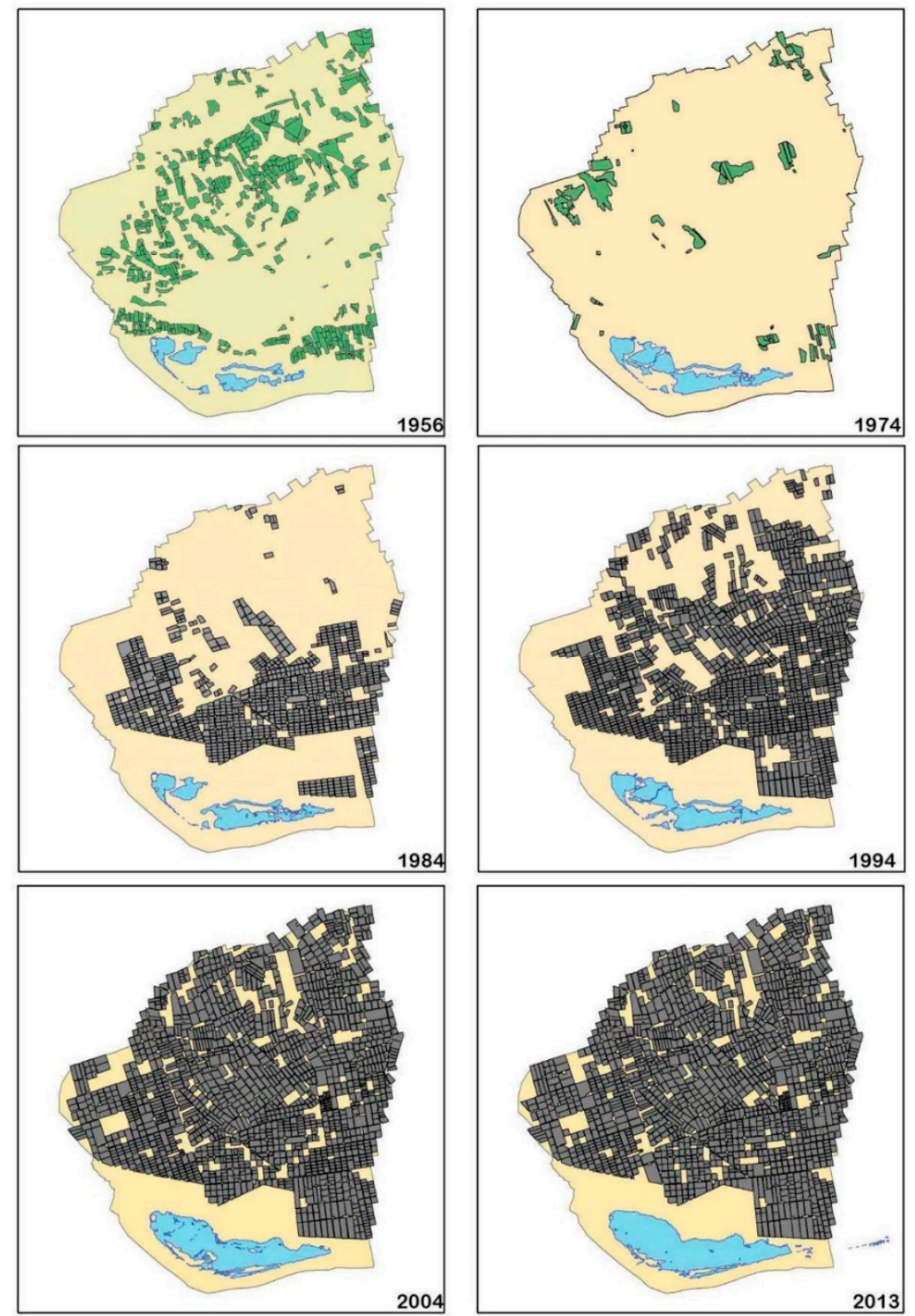

Figure 3. Evolution of the area occupied by greenhouses (gray) and traditional crops (green) and the wetland Puntas Entinas in its drainage basin. The flooded area of the wetland is shown (blue). Modified from [28].

\section{Discussion}

Agriculture is the most intense human-related activity in the entire $C D$ with a notable increase in the land area occupied by greenhouses, which was sharp and continuous between 1960 (30 ha) and $2004(19,665 \mathrm{ha})$. Since then, the surface area has remained very stable, with values close to 20,000 ha. This increase in greenhouses is associated with an increase in the extraction of groundwater. This exploitation has not been uniform for the two aquifers in the area, where two periods exhibiting different behavior can be distinguished: before and after the hydrological year 1990-1991 (Figure 4). There was a significant general decrease in the volume extracted in the shallow aquifer. In the period from 1974 to 1991 , values ranged from $10 \times 10^{6} \mathrm{~m}^{3}$ /year to $18 \times 10^{6} \mathrm{~m}^{3} /$ year, giving average values of $14 \times 10^{6} \mathrm{~m}^{3}$ /year. From 1991 onwards, they gradually decreased and remained very stable, fluctuating between 10 and $5 \times 10^{6} \mathrm{~m}^{3} /$ year, with an average value of $7 \times 10^{6} \mathrm{~m}^{3}$ /year. In deep aquifers, the trend is reversed. In the period from 1974 to 1991 , the average exploitation in the two aquifers was $57 \times 10^{6} \mathrm{~m}^{3} /$ year, reaching a maximum in the year 1990-1991 (73 × 10 $0^{6} \mathrm{~m}^{3}$ /year). From this date onwards, exploitation increased 
substantially, with average values of $115 \times 10^{6} \mathrm{~m}^{3} /$ year and the highest values being recorded in 2017-2018 $\left(174 \times 10^{6} \mathrm{~m}^{3} /\right.$ year $)$.

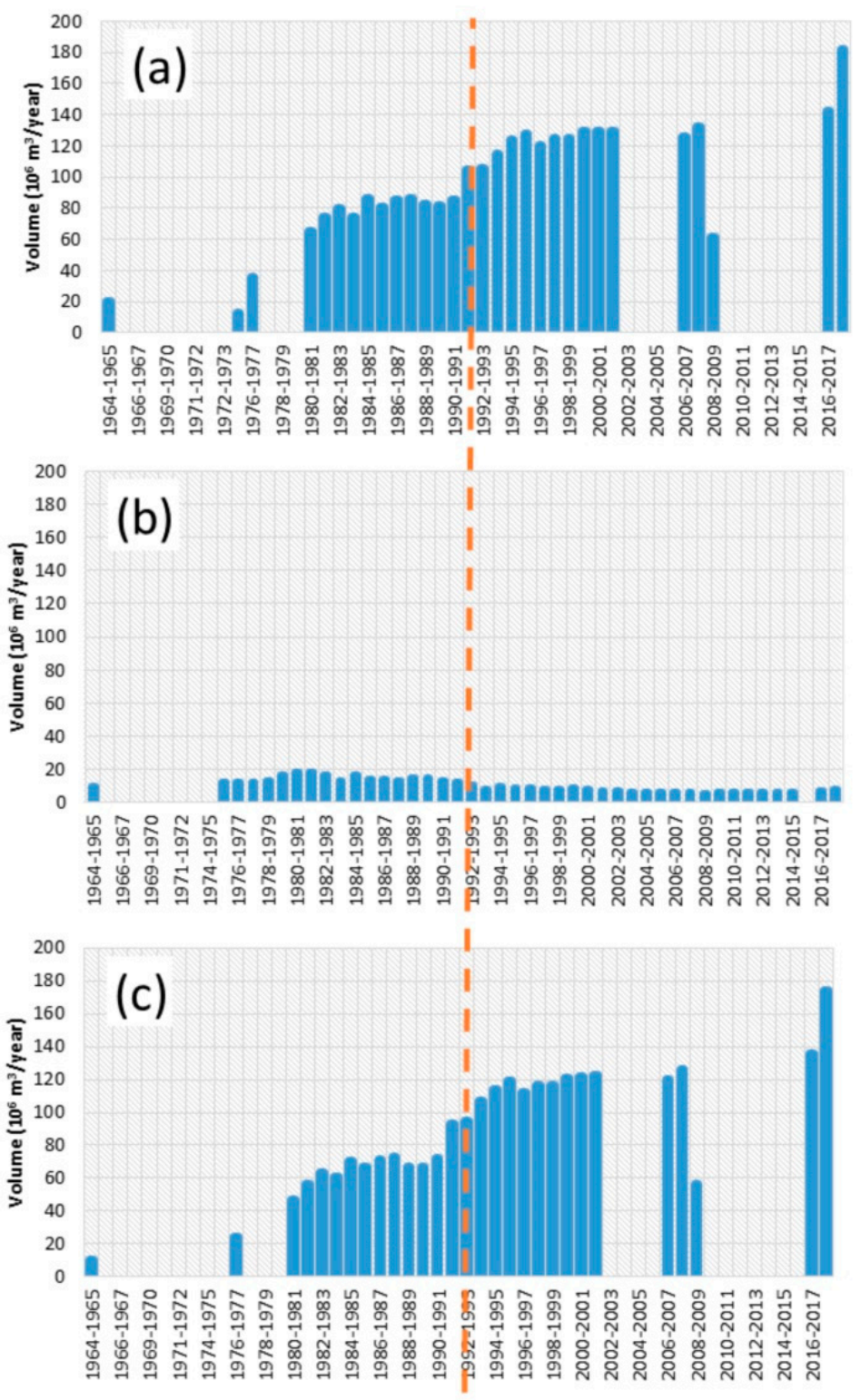

Figure 4. Evolution of groundwater exploitation for (a) the whole area of Campo de Dalías, (b) shallow aquifers, and (c) deep aquifers (in blank: there is no data). The vertical line corresponds to the date that separates the two periods defined, according to the evolution of surface water pumpings.

This regime of exploitation is shown in the variation of the water table for a series of points over 45 years (Figure 5). The initial piezometric data from the shallow aquifer unit (1973) showed elevations of $15 \mathrm{~m}$ above sea level (m.a.s.l.). The piezometric evolution (Figure 6b) of four points near the wetland shows a continuous rise in levels, reaching values of 27-37 m.a.s.l. In contrast, the deep aquifer units show dramatic decreases in the piezometric level, reaching levels below sea level ( -10 and -45 m.a.s.l.) (Figure $5 a)$. In both cases, the trends are slightly different. From 1990-1991, the rise in the water table elevation in the shallow aquifer speeds up, while in the deep aquifer the downward trend continues. The last few years have experienced a notable increase for certain points, as a consequence of the intense rainfall events in 2009/2010 (La Mojonera: $780 \mathrm{~mm}$ /year, compared with an average rainfall of $230 \mathrm{~mm} /$ year). However, the most significant factor has been decreasing the exploitation of the shallow aquifer and the shift to the exploitation 
of the deepest aquifer, which has better quality water. In short, the changing groundwater abstraction regime is responsible for piezometric evolution with generally opposing trends in the two aquifers, which becomes slightly more accentuated from 1991 onwards.
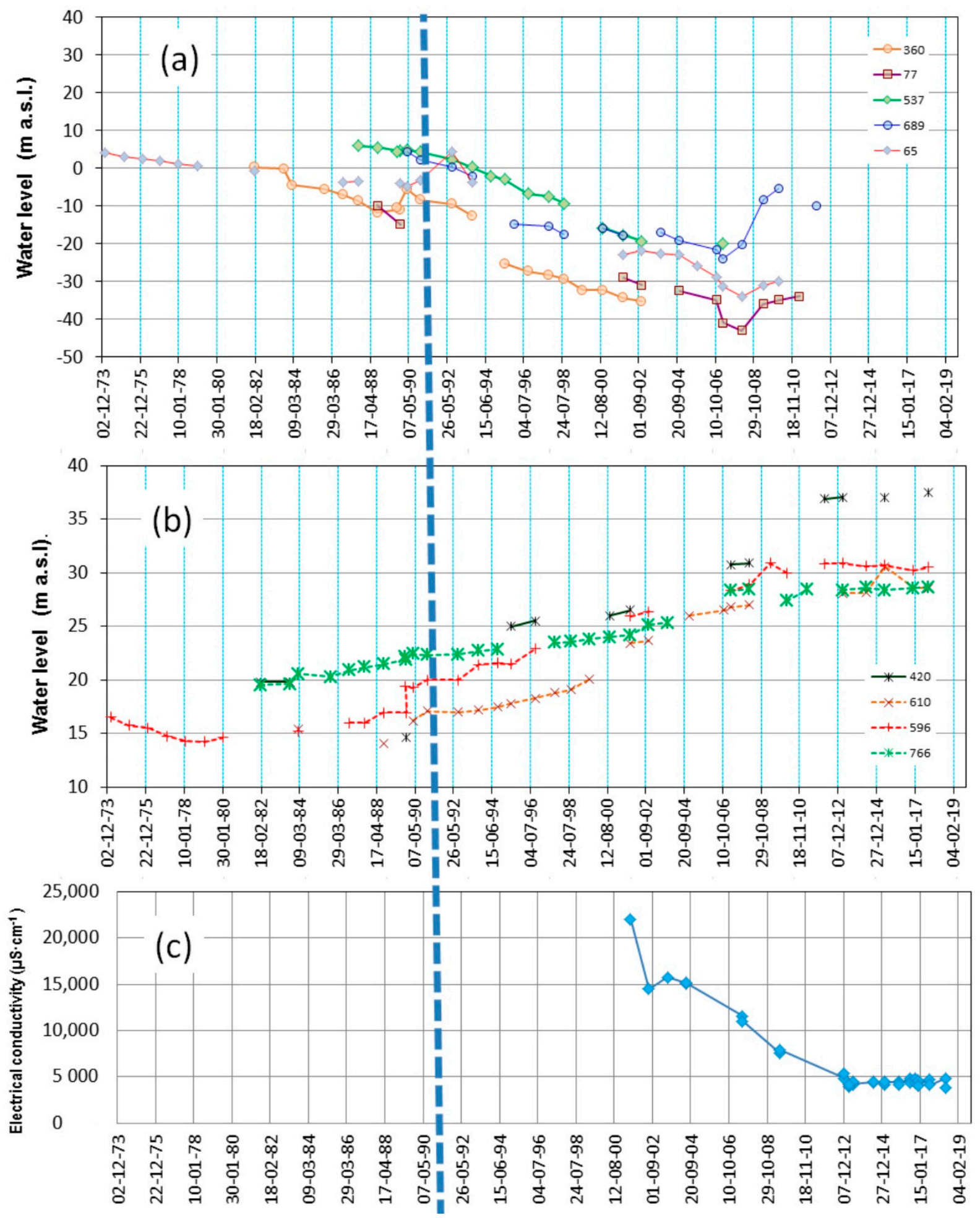

Figure 5. Historical evolution of water levels in the (a) deep aquifer, and in the (b) shallow aquifer location of the points in Figure 1, (c) surface water electrical conductivity in the Balsa del Sapo wetland. Point location in Figure 1. The vertical line corresponds to the date that separates the two periods defined, according to the evolution of surface water pumping. 


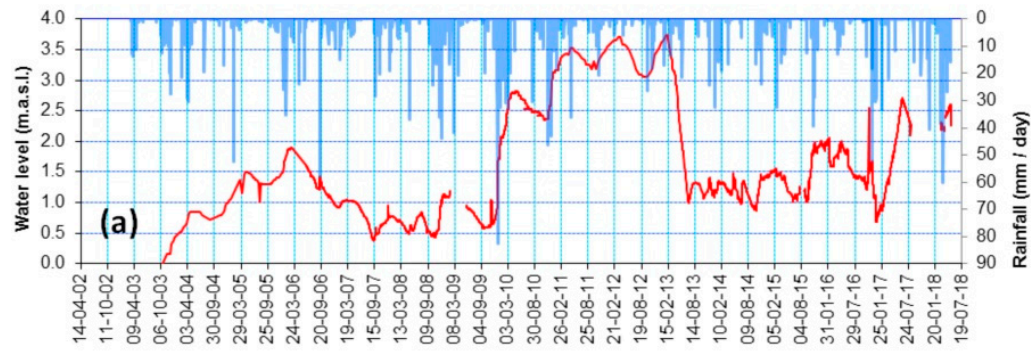

(b)

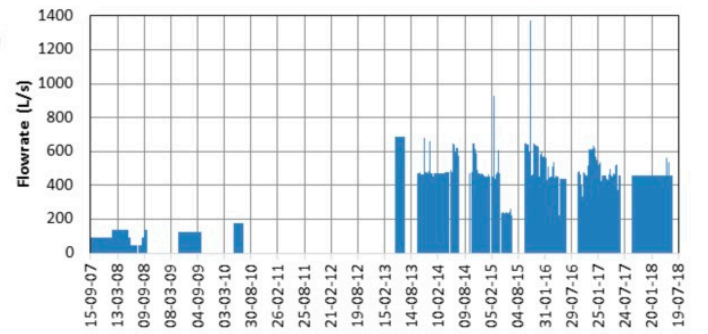

Figure 6. (a) Evolution of surface water elevation (wetland Balsa del Sapo) and rainfall (La Mojonera) in the period 2003-2016; (b) average daily pumped flow. Location of the rainfall station in Figure 1a.

Considering the extensive time series data analyzed, satellite images (1956-2013), evolution of the water table (1973-2019), and exploitation of different aquifers (1964-2017), it is observed that the piezometric evolution of the shallow aquifer significantly affects: (a) the Punta Entinas wetland that shows an increase in flooded surface area, especially pronounced since 1994 (Figure 3), and (b) the origin and evolution of Balsa del Sapo wetland, where the surface water level has risen considerably.

At the end of the 90s, the presence of water was detected at the base of the quarries for the extraction of silt and clay, located in the inland part of the CD [25], starting off a continuous increase in the surface water, leading to their current state of being totally flooded.

Since October 2003, the surface water elevation in the wetland has been monitored and the data show a very irregular general trend (Figure 6). In the period from 2003 to 2006, it showed an upward trend of about $50 \mathrm{~cm} /$ year which caused the flooding of nearby agricultural facilities. Because of this problem, surface water pumping was initiated with average flows of $180 \mathrm{~L} / \mathrm{s}$. Consequently, in the period 2006-2007, the level dropped by about $1.5 \mathrm{~m}$. Between 2009 and 2010, there was a general rise in levels (>2 m) probably associated with the high rainfall in that period $(780 \mathrm{~mm} /$ year, which was double the average value), and the irregular operation of the pumping station [25]. According to these data, it can be observed that the evolution of the surface water elevation includes a certain seasonal component, which is sporadically influenced by rainfall. Specifically, in the period with no pumping (July 2010-April 2013) the surface water elevation increased by $1.5 \mathrm{~m}$, with more pronounced variations associated with periods of intense rainfall. Subsequently, when an average pumping rate of around $500 \mathrm{~L} / \mathrm{s}$ was maintained, the water level varied between 1-2 m above the level initially measured in 2003, when the data were first recorded. From this date onwards, the water level has remained relatively stable, with some occasional fluctuations, related to short periods in which surface water pumping stopped and there was intense rainfall (Figure 6). The need for continued pumping to keep the wetland level stable suggests that there must be other factors, in addition to rainfall, that have a significant impact on the hydrological regime of the wetland.

Furthermore, it affects the chemical composition of the surface water in the two wetlands, whose characteristics are different because of its geographical position. Punta Entinas wetland is coastal and its waters are sodium chloride rich and have high salinity $\left(3337-73,200 \mu \mathrm{S} \cdot \mathrm{cm}^{-1}\right)$, and in Balsa del Sapo wetland, waters are magnesium-sodium chloride and have lower salinity $\left(4500-20,000 \mu \mathrm{S} \cdot \mathrm{cm}^{-1}\right)$ (Figure 5c, Figure 7 and Table 1 ). However, the temporal evolution in both cases show remarkable similarities. 


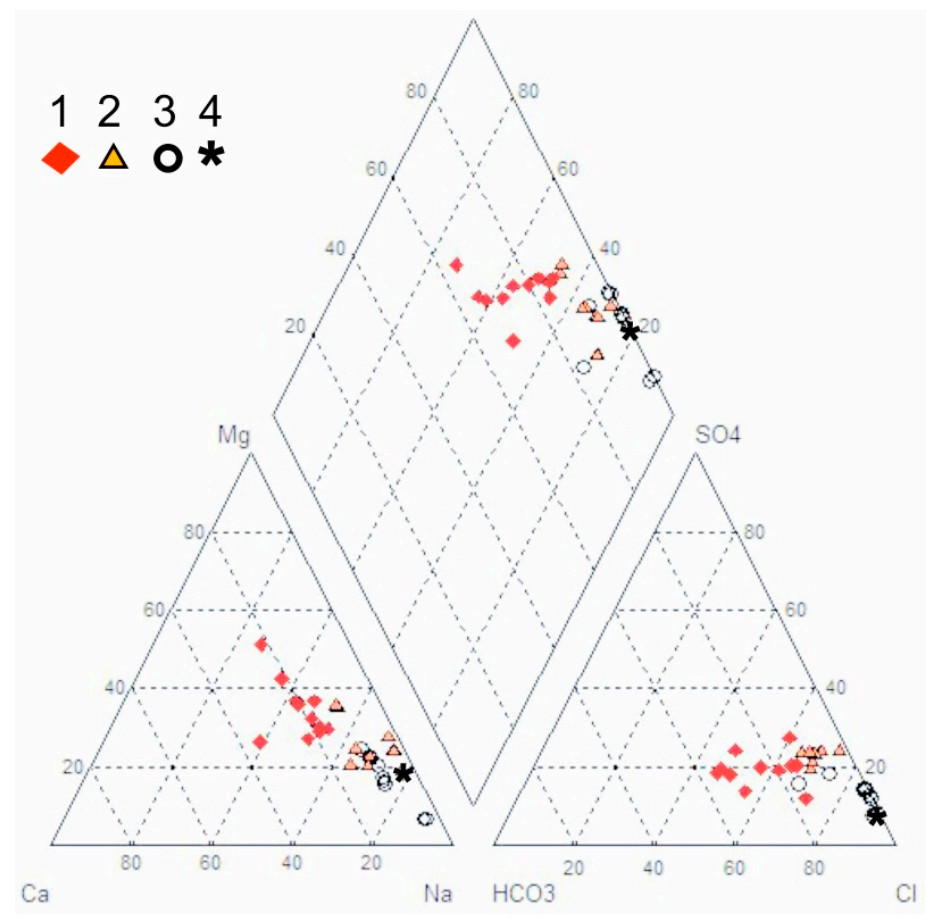

Figure 7. Piper diagram of hydrochemical data. 1: shallow aquifer; 2: Balsa del Sapo; 3: Punta Entinas; 4: sea water. Point location in Figure 1a. Balsa del Sapo data from [25].

In the inland wetland, the salinity of the surface water is undergoing a downward trend. Initially the values were very high $\left(20,000 \mu \mathrm{S} \cdot \mathrm{cm}^{-1}\right)$ probably because of the reduced thickness of the surface water and intense evaporation, which favors the process of salt concentration (Figure 5c), showing a direct relationship between the decrease in salinity and the increase in the surface water elevation. We have data from a series of nine years and studying the ions $\mathrm{Cl}^{-}$vs. $\mathrm{SO}_{4}{ }^{2-}, \mathrm{Cl}^{-}$vs. $\mathrm{Na}^{+}$, and $\mathrm{Cl}^{-}$vs. $\mathrm{Mg}^{2+}$ together (Figure 8), they show a ratio close to that of shallow aquifer (Table 1). The variation of the wetland data shows a decrease in salinity and salt content with values increasingly similar to those of the shallow aquifer [25] (Figures 7 and 8).

Punta Entinas data does not allow such an extensive temporal analysis, but it does allow for the identification of the groundwater influence. Four points have a salinity close to that of seawater $\left(44,500-73,200 \mu \mathrm{S} \cdot \mathrm{cm}^{-1}\right)$ and the content of $\mathrm{Cl}^{-}, \mathrm{SO}_{4}{ }^{2-}$, and $\mathrm{Na}^{+}$is very similar to seawater (Figure 8 ). The values of the remaining points can be found midway between seawater and groundwater and reflect the localized groundwater influence on the wetland. The influence is less pronounced than in the inland wetland, due to the difference between seawater and groundwater chemistry. This is coupled with the processes of salt concentration related to the evaporation that occurs, which makes it difficult to detect accurately. The influence of groundwater is especially evident in the inner part of the wetland, an area where the mapping of the surface water in the oldest images 1956-1984 (Figure 3) shows an elongated area completely flooded with water. 

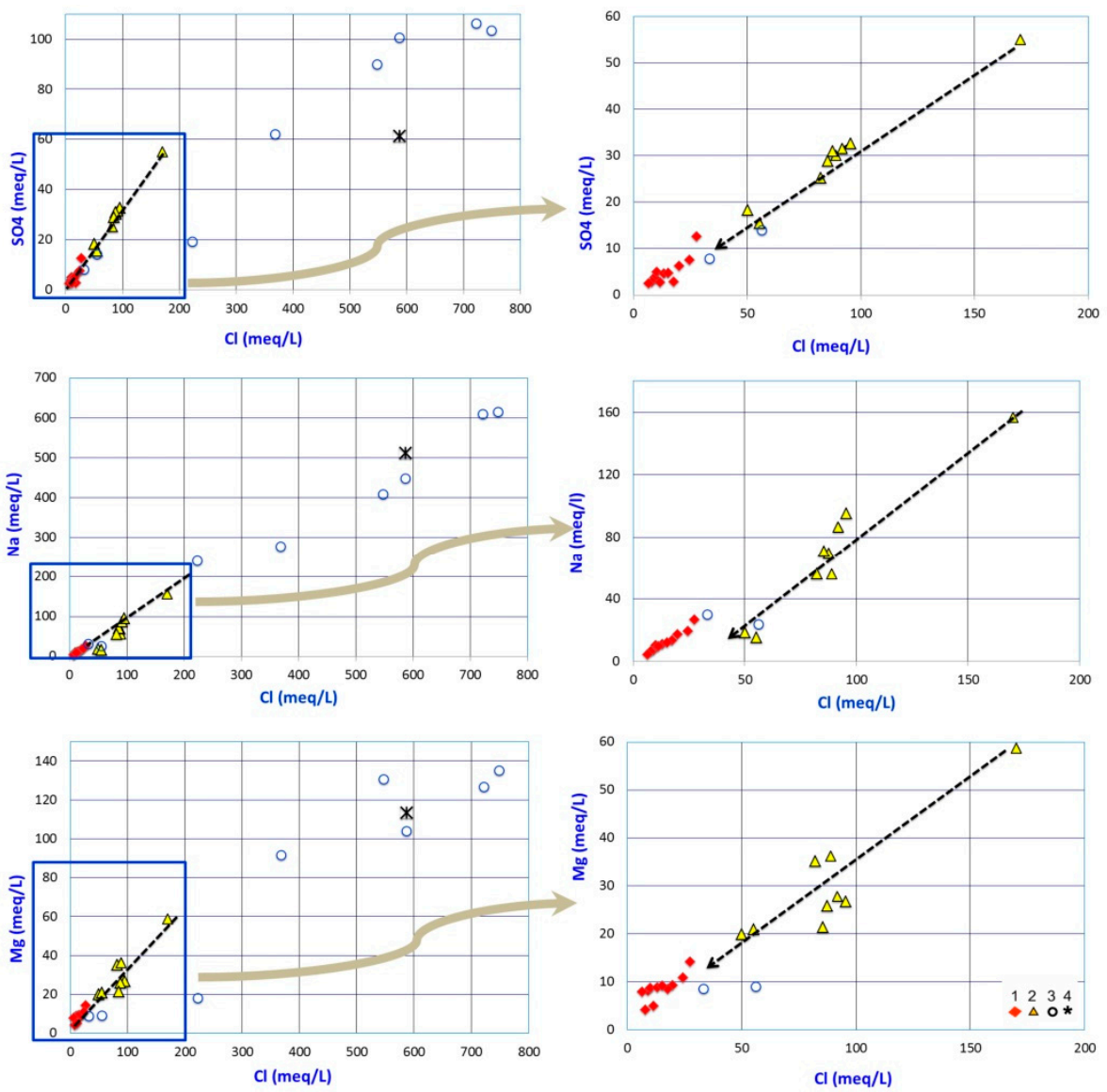

Figure 8. Ionic ratios in surface water of coastal and inland wetlands and groundwater of shallow aquifer. 1: shallow aquifer. 2: Balsa del Sapo. 3: Punta Entinas. 4: Sea water. Point location in Figure 1a. The arrow in the graphs to the right shows the time evolution of surface water in the Balsa del Sapo wetland. Balsa del Sapo data from [25].

\section{Conclusions}

Agriculture is the most important human activity in the entire Campo de Dalías, with a noticeable increase in the surface area occupied by greenhouses, which has been steady and steep since 1960. An extensive series of diverse data has been analyzed: aerial and satellite images (1956-2013), evolution of the water table (1973-2019), and exploitation of different aquifers (1964-2017). The results of this analysis indicate: (1) increase in the surface area occupied by greenhouses, (2) increase in abstraction of groundwater, and (3) an opposite trend in the piezometric evolution of the two aquifers (deep and shallow). The combination of all these factors has clearly affected the evolution of the Punta Entinas wetland, which has shown a continuous increase in flooded surface area, especially marked since 1994.

The hydrochemical data from the shallow aquifer show intermediate characteristics between seawater and groundwater. This influence of groundwater on the wetland is particularly evident in the innermost part of the wetland, further away from the sea. This observation is coherent with the development and evolution of the Balsa del Sapo inland wetland, which is directly dependent on groundwater.

The joint analysis of a series of temporal and spatial data has improved the interpretation of the factors at play in the wetland environment. The application of this methodology is particularly important in areas with significant human activity that has led to changes in land use and intensive groundwater exploitation. Knowledge of this surface watergroundwater dependency is necessary for wetland management, especially in areas with extensive human activity where there is heavy use of groundwater. 
Author Contributions: Conceptualization, F.S.-M. and L.M.S.; methodology, F.S.-M., L.M.S. and J.G.G.; investigation, J.M.L.-M. and F.N.-M.; data, F.S.-M., L.M.S. and J.M.L.-M.; writing-original draft preparation, F.S.-M., L.M.S. and J.M.L.-M.; writing—review and editing, F.S.-M. and L.M.S.; funding acquisition, F.S.-M. All authors have read and agreed to the published version of the manuscript.

Funding: This research has been supported by the project P11-RNM-8115 financed by the Andalusian Regional Government and project PPUENTE2020/012 financed by the University of Almeria 2020 Research and Transfer Plan.

Institutional Review Board Statement: Not applicable.

Informed Consent Statement: Not applicable.

Data Availability Statement: The data presented in this study are available on request from the corresponding author. The data presented in this study are available in [25].

Acknowledgments: This research is a contribution by the Water Resources and Environmental Geology research group (at the Andalusian Regional Government (RNM-189)) for the Campus of International Excellence of the Sea "CEIMAR". The surface water level elevation in the wetland has been monitored by the El Ejido municipal council. We are grateful for the helpful corrections and suggestions made by reviewers, which improved the article.

Conflicts of Interest: The authors declare no conflict of interest.

\section{References}

1. Tiner, R.W. Wetlands: An Overview. In Remote Sensing of Wetlands. Applications and Advances; Tiner, R.W., Lang, M.L., KLemas, V.V., Eds.; CRC Press, Taylor \& Francis Group: Boca Raton, FL, USA, 2015; pp. 3-18.

2. Álvarez-Rogel, J.; Jiménez-Cárceles, F.J.; Roca, M.J.; Ortiz, R. Changes in soils and vegetation in a Mediterranean coastal salt marsh impacted by human activities. Estuar. Coast. Shelf. Sci. 2007, 3-4, 510-526. [CrossRef]

3. Junk, W.J.; An, S.; Finlayson, C.M.; Gopal, B.; Květ, J.; Mitchell, S.A.; Mitsch, W.J.; Robarts, R.D. Current state of knowledge regarding the worlds wetlands and their future under global climate change: A synthesis. Aquat. Sci. 2013, 75, 151-167. [CrossRef]

4. Liao, A.P.; Chen, L.J.; Chen, J.; He, C.Y.; Cao, X.; Chen, J.; Peng, S.; Sun, F.; Gong, P. High-resolution remote sensing mapping of global land water. Sci. China Earth Sci. 2014, 57, 2305-2316. [CrossRef]

5. Verpoorter, C.; Kutser, T.; Seekell, D.A.; Tranvik, L.J. A global inventory of lakes based on high-resolution satellite imagery. Geophys. Res. Lett. 2014, 41, 6396-6402. [CrossRef]

6. Feng, M.; Sexton, J.O.; Channan, S.; Townshen, J.R. A global, high-resolution (30-m) inland water body dataset for 2000: First results of a topographic-spectral classification algorithm. Int. J. Digit. Earth. 2015, 9, 113-133. [CrossRef]

7. Carroll, M.; Wooten, M.; DiMiceli, C.; Sohlberg, R.; Kelly, M. Quantifying Surface Water Dynamics at 30 Meter Spatial Resolution in the North American High Northern Latitudes 1991-2011. Remote Sens. 2016, 8, 622. [CrossRef]

8. Pietroniro, A.; Prowse, T.; Peters, D.L. Hydrologic assessment of an inland freshwater delta using multi-temporal satellite remote sensing. Hydrol. Process. 1999, 13, 2483-2498. [CrossRef]

9. Krinner, G. Impact of lakes and wetlands on boreal climate. J. Geophys. Res. 2003, 108, 4520. [CrossRef]

10. Fox, R.J.; Fisher, T.R.; Gustafson, A.B.; Jordan, T.E.; Kana, T.M.; Lang, M.W. Searching for the missing nitrogen: Biogenic nitrogen gases in groundwater and streams. J. Agric. Sci. 2014, 152, 96-106. [CrossRef]

11. Winter, T.C. Relation of streams, lakes, and wetlands to groundwater flow systems. Hydrogeol. J. 1999, 7, 28-45. [CrossRef]

12. Becker, M.W. Potential for satellite remote sensing of ground water. Groundwater 2006, 44, 306-318. [CrossRef] [PubMed]

13. Mediterranean Wetlands Observatory. Land Cover-Spatial Dynamics in Mediterranean Coastal Wetlands from 1975 to 2005 ; Thematic Collection; Issue \#2; Tour du Valat: Arles, France, 2014; p. 7.

14. Mitsch, W.J.; Gosselink, J.G. Wetlands, 5th ed.; John Wiley \& Sons: Hoboken, NJ, USA, 2015.

15. Jin, H.; Huang, C.; Lang, M.W.; Yeo, I.Y.; Stehman, S. Monitoring of wetland inundation dynamics in the Delmarva Peninsula using Landsat time-series imagery from 1985 to 2011. Remote Sens. Environ. 2017, 190, 26-41. [CrossRef]

16. Castañeda, C.; Herrero, J. Assessing the degradation of saline wetlands in an arid agricultural region in spain. Catena 2008, 72, 205-213. [CrossRef]

17. Martínez-López, J.; Carreño, M.F.; Martínez-Fernández, J.; Esteve, M.A. Wetland and landscape indices for assessing the condition of semiarid Mediterranean saline wetlands under agricultural hydrological pressures. Ecol. Indic. 2014, 36, 400-408. [CrossRef]

18. Adams, J.B.; Bate, G.C. Ecological implications of tolerance of salinity and inundation by Spartina maritima. Aquat. Bot. 1995, 52, 183-191. [CrossRef]

19. Allen, Y.C.; Couvillion, B.R.; Barras, J.A. Using Multitemporal Remote Sensing Imagery and Inundation Measures to Improve Land Change Estimates in Coastal Wetlands. Estuaries Coasts 2012, 35, 190-200. [CrossRef]

20. Pulido-Bosch, A.; Vallejos, A.; Sola, F.; Molina, L. Groundwater Sustainability Strategies in the Sierra de Gador-Campo de Dalías System, Southeast Spain. Water 2020, 12, 3262. [CrossRef] 
21. Mendoza-Fernández, A.J.; Peña-Fernández, A.; Molina, L.; Aguilera, P.A. The Role of Technology in Greenhouse Agriculture: Towards a Sustainable Intensification in Campo de Dalías (Almería, Spain). Agronomy 2021, 11, 101. [CrossRef]

22. Martínez-Santos, P.; Martínez-Alfaro, P.E. Estimating groundwater withdrawals in areas of intensive agricultural pumping in central Spain. Agric. Water Manag. 2018, 98, 172-181. [CrossRef]

23. Iglesias, A.; Garrote, L.; Flores, F.; Moneo, M. Challenges to manage the risk of water scarcity and climate change in the Mediterranean. Water Resour. Manag. 2007, 21,775-788. [CrossRef]

24. Pulido-Bosch, A.; Bensi, S.; Molina, L.; Vallejos, A.; Calaforra, J.M.; Pulido-Leboeuf, P. Nitrates as indicators of aquifer interconnection. Application to the Campo de Dalías (SE-Spain). Environ. Geol. 2000, 39, 791-799. [CrossRef]

25. Molina-Sánchez, L.; Sánchez-Martos, F.; Daniele, L.; Vallejos, A.; Pulido-Bosch, A. Interaction of aquifer-wetland in a zone of intensive agriculture: The case of Campo de Dalías (Almería, SE Spain). Environ. Earth Sci. 2005, 73, 2869-2880. [CrossRef]

26. Pulido Bosch, A.; Pulido-Leboeuf, P.; Molina-Sánchez, L.; Vallejos, A.; Martín Rosales, W. Intensive agriculture, wetlands, quarris and water management. A case study (Campo Dalías, SE Spain). Environ. Geol. 2000, 40, 163-168. [CrossRef]

27. Goy, J.L.; Zazo, C.; Dabrio, C.J. A beach-ridge progradation complex reflecting periodical sea-level and climate variability during the Holocene (Gulf of Almería, Western Mediterranean). Geomorphology 2003, 50, 251-268. [CrossRef]

28. López Martos, J.M. Transformaciones de un humedal incrustado en un paisaje del Antropoceno. El caso de los Charcones de Entinas. Bachelor's Thesis, University of Almeria, Almería, Spain, 2015. 